\title{
REGIONAL TRAINING INSTITUTE IN WEST AFRICA
}

The League of Red Cross Societies selected Lomé, capital of Togo, for the Red Cross Regional Training Institute seminar held from 3 to 15 September 1973. The welcome and the support given by the Togolese authorities and Red Cross and the very appropriate setting of the Maison du Parti du Rassemblement du Peuple Togolais augured well for the event. The League was represented by Mr. Kilde, Assistant Director of the Relief Preparedness Bureau; Mr. Elliot, Training Adviser; Mr. Grunfeld, Regional Delegate, and Mrs. Pejovic, Assistant to the Regional Officer for Africa. The ICRC was represented by Mr. Boissier, Director of the Henry Dunant Institute.

The Red Cross is in the first place an ideal, but it is also an administration despite its unusually large number of voluntary workers. The seminar was therefore of more immediate concern to the administrators of the National Societies of the following nine French-speaking countries of West Africa: Cameroon, Dahomey, the Ivory Coast, Mali, Mauritania, the Niger, Senegal, Togo and the Upper Volta.

Administering is a far more complex activity than one might think. A good administrator should be able to detect needs that must be met, establish priorities, pinpoint targets and plan action. He must administer assets and co-ordinate the activities of those working under his supervision.

The courses covering all these subjects were conducted by senior Togolese officials from the Ministries of Foreign Affairs, Finance and Education. The participants were all agreed as to the high level of the courses, which had been carefully prepared by Mr. Edouard Kodjo, Minister of Finance of the Togolese Republic, who himself conducted them. Like others before it, the Lomé Institute called upon local teachers more aware than anyone else of the problems with which the Red Cross had to contend in that area.

From beginning to end, the participants were required to take an active part in the seminar. Under the guidance of a Togolese 
expert in group dynamics, all manner of discussion and practical work led to fruitful exchanges and the assimilation of data.

Twice the participants went out into the field, and not just as tourists-much as they enjoyed the experience-but to make a practical assessment of the needs of rural communities. Those needs were manifold, sometimes pitiful, and some were beyond actual Red Cross capacity. Hence the necessity to make a judicious choice and to explain to the villagers the reasons for certain measures which would improve conditions. Progress was not something that could be imposed. It was the result of co-operation by those directly concerned. The road was still encumbered by some old habits which would gradually have to be changed through sustained, prolonged and methodical effort. To give advice about the making and use of water filters was not enough. The first requirement was to make people realize the connection between certain diseases and such redoubtable parasites as the Guinea worm, or drinking water from the nearby stream rich in unseen dangers. In her closing address, Mrs. Eyadema, Honorary President of the Togolese Red Cross and wife of the President of the Republic, rightly stressed this particular aspect when she said:

"All of you are called upon to meet needs which are sometimes very great, with resources which are always slender. But there is one resource which should never be lacking, and that is active co-operation from those you propose to help. To secure that co-operation you must, above all, act as organizers and educators. You must rouse energy and initiative. This is not an easy matter, but it is vital, the prerequisite of success. I know you see it as one of the most evident results of your work." 